\title{
KADAR KLOROFIL DAUN PAKCOY (BRASSICA CHINENSIS L.) SETELAH PERLAKUAN PUPUK KANDANG DAN AMPAS TAHU SEBAGAI BAHAN AJAR MATA KULIAH FISIOLOGI TUMBUHAN
}

\author{
Stenly Jacob Wenno ${ }^{1}$, H. Sinay ${ }^{2}$ \\ ${ }^{1}$ Alumni Program Studi Pendidikan \\ ${ }^{2}$ Dosen Program Studi Pendidikan Biologi \\ Email: herlinbio@yahoo.co.id
}

\begin{abstract}
Background: Pakcoy (Brassica chinensis L.) is a vegetable plant originating from China that has leaf stalks that are wider and larger than green mustard greens. Pakcoy has nutritional value such as vitamin C, vitamin A, carbohydrates, fiber, protein, calcium, magnesium. Chlorophyll is a green leaf substance found in green parts of plants, especially on leaves. One of the factors that influence the chlorophyll content in pakcoy mustard leaves is the soil condition in this case the nutrient content and nutrients in the soil. One way to meet nutrient and nutrient content in the soil is by using organic fertilizers such as manure and tofu.

Method: This study aims to determine the chlorophyll content of pakcoy leaves (Brassica chinensis L.) after giving manure and tofu dregs. Based on the analysis of chlorophyll content using the UV-VIS spectrophotometer method at wavelengths of $644 \mathrm{~nm}$ and $663 \mathrm{~nm}$.

Results: The highest levels of chlorophyll A in pakcoy (Brassica chinensis L.) leaves with PK3AT1 treatment $(7 \mathrm{~kg}$ manure and $7 \mathrm{~kg}$ tofu dregs) of $2.007 \mathrm{mg} / \mathrm{L}$, highest chlorophyll B levels in pakcoy (Brassica chinensis L.) leaves with treatment PK3AT3 (7 kg manure and tofu dregs $3 \mathrm{~kg}$ ) at $2.674 \mathrm{mg} /$ $\mathrm{L}$, and the highest total chlorophyll content in pakcoy (Brassica chinensis L.) leaves with PK3AT1 treatment (7 kg manure and $7 \mathrm{~kg}$ tofu dregs) at $4,558 \mathrm{mg} / \mathrm{L}$.

Conclusion: Chlorophyll A, B and total levels in pakchoy (Brassica chinensis L.) leaves after a combination of manure and tofu dregs have high levels of different corophils.
\end{abstract}

Keywords: Pakcoy leaf (Brassica chinensis L.), manure, tofu, chlorophyll

\begin{abstract}
Abstrak
Latar Belakang: Pakcoy (Brassica chinensis L.) merupakan tanaman sayuran yang berasal dari China yang memiliki tangkai daun yang lebih lebar dan besar dibandingkan sawi hijau. Pakcoy memiliki nilai gizi seperti vitamin $\mathrm{C}$, vitamin $\mathrm{A}$, karbohidrat, serat, protein, kalsium, magnesium. Klorofil merupakan zat hijau daun yang terdapat pada bagian tumbuhan yang berwarna hijau khususnya pada daun. Salah satu faktor yang mempengaruhi kandungan klorofil pada daun sawi pakcoy adalah kondisi tanah dalam hal ini kandungan hara dan nutrisi di dalam tanah. Salah satu cara untuk memenuhi kandungan hara dan nutrisi dalam tanah yaitu dengan menggunakan pupuk organik seperti pupuk kandang dan ampas tahu.

Metode: Penelitian ini bertujuan untuk mengetahui kadar klorofil pada daun pakcoy (Brassica chinensis L.) setelah pemberian pupuk kandang dan ampas tahu. Berdasarkan hasil analisis kadar klorofil menggunakan metode Spektrofotometer UV-VIS pada panjang gelombang $644 \mathrm{~nm}$ dan 663 $\mathrm{nm}$.

Hasil: Kadar klorofil A tertinggi pada daun pakcoy (Brassica chinensis L.) dengan perlakuan $\mathrm{PK}_{3} \mathrm{AT}_{1}$ (Pupuk kandang $7 \mathrm{~kg}$ dan ampas tahu $7 \mathrm{~kg}$ ) sebesar $2,007 \mathrm{mg} / \mathrm{L}$, kadar klorofil B tertinggi pada daun pakcoy (Brassica chinensis L.) dengan perlakuan $\mathrm{PK}_{3} \mathrm{AT}_{3}$ (Pupuk kandang $7 \mathrm{~kg}$ dan ampas tahu $3 \mathrm{~kg}$ ) sebesar 2,674 $\mathrm{mg} / \mathrm{L}$, dan kadar klorofil total tertinggi pada daun pakcoy (Brassica chinensis L.) dengan perlakuan $\mathrm{PK}_{3} \mathrm{AT}_{1}$ (Pupuk kandang $7 \mathrm{~kg}$ dan ampas tahu $7 \mathrm{~kg}$ ) sebesar $4,558 \mathrm{mg} / \mathrm{L}$.

Kesimpulan: Kadar klorofil A, B dan total pada daun pakchoy (Brassica chinensis L.) setelah kombinasi pupuk kandang dan ampas tahu memiliki tinggi kadar korofil yang berbeda.
\end{abstract}

Kata Kunci: Daun pakcoy (Brassica chinensis L.), pupuk kandang, ampas tahu, klorofil 


\section{PENDAHULUAN}

Sawi merupakan jenis sayuran yang banyak digemari oleh masyarakat. Terdapat berbagai jenis sawi yang saat ini beredar di pasaran dan dikonsumsi oleh masyarakat. Salah satu jenis sawi yang juga digemari dan sudah populer adalah sawi pakcoy. Pakcoy (Brassica chinensis L.) merupakan tanaman sayuran yang berasal dari China dan telah dibudidayakan setelah abad ke-5 secara luas di China selatan dan China pusat serta Taiwan. Tanaman ini berkembang pesat di daerah sub tropis maupun tropis (Murti dkk. 2016).

Pakcoy memiliki nilai gizi seperti vitamin $C$, vitamin, $A$, karbohidrat, serat, protein, lemak nabati yang diperlukan oleh tubuh untuk menjaga kesehatan didalam tanaman pakcoy terkandung zat betakaroten yang tinggi yang dapat mencegah penyakit katarak. (Sadewa, 2016). Menurut (Hidayat., dkk. 2014) pakcoy juga mengandung gizi protein, lemak nabati, karbohidrat, serat, $\mathrm{Ca}, \mathrm{Mg}$, $\mathrm{Fe}, \mathrm{Na}$, Vitamin A dan vitamin C. Selain kandungan gizi, mineral dan vitamin, sayuran berhijau daun seperti sawi hijau jenis pakcoy juga merupakan salah satu sumber klorofil yang bermanfaat bagi tubuh manusia. Dengan warna daunnya yang lebih hijau gelap dibandingkan jenis sawi hijau caisim, diduga bahwa kandungan klorofil pada daun sawi hijau pakcoy ini lebih tinggi dari jenis sawi hijau yang lain.

Klorofil merupakan zat hijau daun yang terdapat pada bagian tumbuhan yang berwarna hijau khususnya pada daun. Kandungan klorofil daun tumbuhan berbeda-beda meskipun jenis tumbuhannya sama. Kandungan klorofil pada daun tumbuhan termasuk juga pada sayuran seperti sawi pakcoy dapat dipengaruhi oleh kondisi lingkungan tumbuhnya. Beberapa faktor yang mempengaruhi kandungan klorofil pada daun sawi pakcoy adalah intensitas cahaya, suhu, dan kondisi tanah (Song-Ai dan Banyo, 2011).

Kondisi tanah yang dapat mempengaruhi kandungan klorofil adalah kandungan hara dan nutrisi di dalam tanah. Dalam budidaya sayuran termasuk sayuran pakcoy saat ini, umumnya petani menmbudidayakan pada lahan bekas olahan yang sudah digunakan berulangulang. Tanah yang digunakan secara berulang telah kehilangan unsur haranya, sehingga dibutuhkan pemupukan tambahan. Umumnya, pemupukan yang dilakukan oleh petani adalah pemupukan sintetis menggunakan pupuk kimia atau pupuk anorganik.

Menurut Parman (2007), dampak dari penggunaan pupuk kimia sintesis menghasilkan peningkatan produktivitas tanaman yang cukup tinggi. Namun penggunaan pupuk kimia sintesis dalam jangka waktu yang relatif lama umumnya berakibat buruk pada kondisi tanah. Tanah menjadi cepat mengeras, kurang mampu menyimpan air dan cepat menjadi asam yang pada akhirnya akan menurunkan produktivitas tanaman. Pemupukan sintetis juga memiliki dampak buruk terhadap kesehatan manusia jika pupuk yang diberikan tertinggal atau terakumulasi pada jaringan tanaman dan dikonsumsi oleh manusia dalam jumlah berlebihan.

Salah satu cara untuk mengatasai penggunaan pupuk kimia sintetis adalah menggunakan pupuk organik yang berasal dari sisa-sisa jaringan tumbuhan maupun hewan. Menurut Napitupulu dan Winarto (2010), Pemupukan merupakan salah satu faktor penentu dalam upaya meningkatkan hasil tanaman. Dengan berkembangnya usaha pertanian beberapa sumber hara yang dapat digunakan dalam sistem pertanian organik adalah bahan organik yang berasal dari pupuk kandang, pupuk hijau, limbah pertanian, pupuk hayati. Pupuk organik umumnya merupakan pupuk lengkap karena mengandung unsur hara makro dan mikro meskipun dalam jumlah sedikit. Penggunaan pupuk kandang atau kompos selama ini diyakini dapat mengatasi permasalahan yang ditimbulkan oleh pupuk anorganik (Parman, 2007).

Pupuk kandang merupakan hasil samping yang cukup penting, berupa kotoran hewan padat atau cair dari hewan ternak yang bercampur sisa makanan. Jika diaplikasikan ke tanah pertanian, pupuk kandang ini dapat menambah unsur hara dalam tanah. Pemberian pupuk kandang selain dapat menambah tersedianya unsur hara, juga dapat memperbaiki sifat fisik tanah seperti kemantapan agregat, bobot volume, total ruang pori, plastisitas dan daya pegang air (Mayadewi, 2007). 
Selain pupuk kandang, pupuk organik lain yang dapat ditambahkan pada lahan budidaya adalah ampas tahu. Ampas tahu merupakan sisa-sisa dari usaha produksi tahu skala industri rumah tangga yang dibuang dan tidak lagi dimanfatkan. Menurut Danial et al. (2009), ampas tahu mengandung unsur hara yang masih dapat dimanfaatkan untuk menambah kesuburan tanah dalam kegiatan atau usaha budidaya yaitu $\mathrm{N}, \mathrm{P}, \mathrm{K}, \mathrm{Ca}, \mathrm{Mg}$, dan $\mathrm{C}$ organik.

Dengan kandungan nutrisi yang terdapat dalam pupuk organik baik pupuk kandang dan ampas tahu, dapat berpengaruh terhadap perbaikan kualitas tanah, pertumbuhan dan perkembangan tanaman, maupun kandungan nutrisi pada tanaman termasuk juga kandungan klorofil. Diketahui bahwa komponen utama penyusun klorofil adalah Nitrogen dan Magnesium. Sebagaimana dinyatakan oleh Suntoro (2002) bahwa kandungan hara di dalam tanah seperti Nitrogen, dan Magnesium merupakan hara yang sangat esensial dalam pembentukan klorofil pada jaringan tanaman. Ningsih (2011) juga menyatakan bahwa penambahan pupuk kandang sapi memberikan pengaruh nyata terhadap peningkatan klorofil $b$ pada tanaman melon.

Penelitian ini berpotensi untuk diimplikasikan dalam mata kuliah fisiologi tumbuhan. Fisiologi tumbuhan merupakan cabang botani yang mempelajari bekerjanya sistem kehidupan di dalam tubuh tumbuhan dan tanggapan terhadap pengaruh lingkungan sekitarnya sehingga tumbuhan tersebut dapat hidup. Untuk itu implikasi dari penelitian ini akan dibuat dalam bentuk bahan ajar. Implikasi hasil penelitian yang dibuat dalam bahan ajar ini dapat membantu untuk menunjang aspek pembudidayaan sawi yang dapat diterapkan pada mahasiswa di perguruan tinggi khususnya bagi mahasiswa program studi pendidikan biologi.

Bahan ajar merupakan salah satu bagian penting dalam proses pembelajaran. Sebagaimana (Mulyasa 2006.) mengemukakan bahwa bahan ajar merupakan salah satu bagian dari sumber ajar yang dapat diartikan sesuatu yang mengandung pesan pembelajaran, baik yang bersifat khusus maupun bersifat umum yang dapat dimanfaatkan untuk kepentingan pembelajaran.

\section{MATERI DAN METODE}

Tipe peneilitan yang digunakan dalam penelitian ini adalah penelitian deskriptif yang berlokasi di Green House Program Studi Pendidikan Biologi FKIP, Laboratorium Biologi Dasar FKIP, dan Laboratorium Mikrobiologi FMIPA Universitas Pattimura Ambon, pada tanggal 23 agustus 2018 sampai dengan 11 Oktober 2018. Yang menjadi Objek penelitian ini adalah daun sawi pakcoy yaitu tiga daun pada setiap tanaman dengan kriteria daun sangat tua, daun setengah tua dan daun muda. Variabel penelitian ini terdiri dari dua macam yaitu variabel bebas: pemberian pupuk kandang dan ampas tahu. Variabel terikat pada penelitian ini adalah kadar klorofil daun pakcoy. Teknik analisis yang digunakan adalah analisis deskriptif yaitu digunakan untuk mendeskripsikan kadar klorofil daun sawi pakcoy setelah pemberian pupuk kandang dan ampas tahu dalam bentuk tabel.

\section{Penentuan Kombinasi Pupuk Kandang dan Ampas Tahu}

Kombinasi pupuk kandang dan ampas tahu yang akan digunakann, diurai sebagai berikut:

Pupuk Kandang (PK) PK1 = Pupuk Kandang $3 \mathrm{~kg}$

PK2 = Pupuk Kandang $5 \mathrm{~kg}$ Ampas Tahu (AT) PK3 = Pupuk Kandang 7 kg

AT1 = Ampas Tahu $7 \mathrm{~kg}$

AT2 = Ampas Tahu $5 \mathrm{~kg}$

AT3 = Ampas Tahu $3 \mathrm{~kg}$

Kemudian dikombinasikan sebagai berikut: 
Tabel 3. Kombinasi Pemberian Pupuk Kandnang Dan Ampas Tahu

\begin{tabular}{cccc}
\hline \multirow{2}{*}{ Pupuk Kandang } & \multicolumn{3}{c}{ Ampas Tahu } \\
\cline { 2 - 4 } & $\mathbf{A T}_{1}$ & $\mathbf{A T}_{\mathbf{2}}$ & $\mathbf{A T}_{3}$ \\
\hline $\mathrm{PK}_{1}$ & $\mathrm{PK}_{1} \mathrm{AT}_{1}$ & $\mathrm{PK}_{1} \mathrm{AT}_{2}$ & $\mathrm{PK}_{1} \mathrm{AT}_{3}$ \\
\hline $\mathrm{PK}_{2}$ & $\mathrm{PK}_{2} \mathrm{AT}_{1}$ & $\mathrm{PK}_{2} \mathrm{AT}_{2}$ & $\mathrm{PK}_{2} \mathrm{AT}_{3}$ \\
\hline $\mathrm{PK}_{3}$ & $\mathrm{PK}_{3} \mathrm{AT}_{1}$ & $\mathrm{PK}_{3} \mathrm{AT}_{2}$ & $\mathrm{PK}_{3} \mathrm{AT}_{3}$ \\
\hline
\end{tabular}

Setiap kombinasi dibuat 3 ulangan. Sebagai pembanding digunakan kontrol (tanpa pemberian pupuk kandang maupun ampas tahu).

\section{Teknik Pengumpulan Data Persiapan Tanah}

Tanah yang dipakai adalah jenis tanah hitam yang bersifat gembur yang didapatkan dari desa suli, kemudian digunakan sebagai media tumbuh tanaman sawi pakcoy atau sampel.

Tanah yang telah disiapkan dimasukan sebanyak $10 \mathrm{~kg}$ kedalam polybag yang berukuran $20 \mathrm{~kg}$, kemudian ditambahkan pupuk kandang dan ampas tahu dengan perbandingan sebagaimana ditunjukan pada rancangan penelitian, campuran tanah, pupuk kandang dan ampas tahu dibiarkan selama 15 hari.

\section{Persiapan Benih}

Biji tanaman sawi yang digunakan sebagai benih diperoleh dari toko Aneka Tani yaitu jenis sawi pakcoy. Biji tanaman pakcoy direndam selama 12 jam dan dipindahkan ke media semai dan disemaikan sampai berumur 10 (sepuluh) hari.

\section{Pemindahan Semaian ke Media Tanam}

Semaian tanaman pakcoy yang telah berumur 10 hari dipindahkan ke media tanam berupah campuran tanah, pupuk kandang, dan ampas tahu yang telah dibuat sebelumnya. Pemindahan semaian dilakukan dengan mengangkat semaian bersama-sama dengan tanah dan akarakarnya.

\section{Pemeliharaan}

Pada tahap pemeliharaan dilakukan penyiraman pada pagi dan sore hari dilakukan setiap hari dengan volume air sesuai kapasitas lapangan. Perawatan tanaman berupa pembumbuan yaitu dengan membuat turus disekitar tanaman dan pencabutan rumput/gulma.

\section{Analisis kadar klorofil daun pakcoy}

Penentuan kadar klorofil mengikuti metode yang dirujuk dari Setiari dan Nurchayati, (2009) dengan sedikit modifikasi. Ditimbang sebanyak $0,1 \mathrm{mg}$ sampel daun dan selanjutnya diekstrak dengan cara direndam dalam larutan alkohol 96\% 1000 $\mathrm{mL}$ selama 1x24 jam (Nurdin dkk. 2009). Ekstrak yang diperoleh disaring dengan kertas saring dan dianalisis dengan menggunakan spektrofotometer UV-VIS pada panjang gelombang $644 \mathrm{~nm}$ dan 663 $\mathrm{nm}$. Penghitungan kadar klorofil (mg/L) ditentukan dengan rumus:

Klorofil a = 1.07 (OD 663) - 0.094 (OD 644) Klorofil b = 1.77 (OD 644) - 0.28 (OD 663) Klorofil total $=0.79(\mathrm{OD} 663)+1.076(\mathrm{OD}$ 644)

\section{HASIL DAN PEMBAHASAN Hasil}

Analisis kadar klorofil pada daun pak choy (Brassica chinensis L.) dilakukan dengan menggunakan metode spektrofotometer UV-VIS pada panjang gelombang $644 \mathrm{~nm}$ dan $663 \mathrm{~nm}$. Dalam penelitian ini, dilakukan analisis kadar klorofil pada tanaman dari setiap kombinasi. Pada tanaman tersebut diambil tiga helaian daun. Dari setiap helaian daun dibuat dua potongan dengan ukuran $1 \times 1 \mathrm{~cm}$ pada sisi kiri dan kanan kemudian digunakan untuk analisis kadar klorofil yakni klorofil a, klorofil b dan klorofil total. Hasil pengukuran kadar klorofil a, b, dan total ditunjukan pada Tabel 4-6 berikut ini: 
Tabel 4. Hasil Perhitungan Kadar Klorofil a Daun Pak Choy (Brassica chinensis L.)

\begin{tabular}{|c|c|c|c|c|c|}
\hline \multirow[b]{2}{*}{ Kombinasi Pupuk } & \multicolumn{3}{|c|}{ Ulangan } & \multirow[b]{2}{*}{ Total } & \multirow{2}{*}{$\begin{array}{c}\text { Rerata Kadar Klorofil } \\
\text { a (mg/L) }\end{array}$} \\
\hline & 1 & 2 & 3 & & \\
\hline $\begin{array}{l}\mathrm{PK}_{1} \mathrm{AT}_{1} \\
\text { (Pupuk kandang } 3 \mathrm{~kg} \text { dan } \\
\text { ampas tahu } 7 \mathrm{~kg} \text { ) }\end{array}$ & 0,484 & 1,092 & 1,594 & 3,17 & 1,056 \\
\hline $\begin{array}{l}\mathrm{PK}_{1} \mathrm{AT}_{2} \\
\text { (Pupuk kandang } 3 \mathrm{~kg} \text { dan } \\
\text { ampas tahu } 5 \mathrm{~kg} \text { ) }\end{array}$ & 0,929 & 1,268 & 0,876 & 3,073 & 1,024 \\
\hline $\begin{array}{l}\mathrm{PK}_{1} \mathrm{AT}_{3} \\
\text { (Pupuk kandang } 3 \mathrm{~kg} \text { dan } \\
\text { ampas tahu } 3 \mathrm{~kg} \text { ) }\end{array}$ & 0,851 & 0,542 & 0,567 & 1,96 & 0,653 \\
\hline $\begin{array}{l}\mathrm{PK}_{2} \mathrm{AT}_{1} \\
\text { (Pupuk kandang } 5 \mathrm{~kg} \text { dan } \\
\text { ampas tahu } 7 \mathrm{~kg} \text { ) }\end{array}$ & 0,673 & 0,650 & 0,441 & 1,764 & 0,588 \\
\hline $\begin{array}{l}\mathrm{PK}_{2} \mathrm{AT}_{2} \\
\text { (Pupuk kandang } 5 \mathrm{~kg} \text { dan } \\
\text { ampas tahu } 5 \mathrm{~kg} \text { ) }\end{array}$ & 0,935 & 0,455 & 0,539 & 1,929 & 0,643 \\
\hline $\begin{array}{l}\mathrm{PK}_{2} \mathrm{AT}_{3} \\
\text { (Pupuk kandang } 5 \mathrm{~kg} \text { dan } \\
\text { ampas tahu } 3 \mathrm{~kg} \text { ) }\end{array}$ & 0,365 & 0,671 & 0,410 & 1,446 & 0,482 \\
\hline $\begin{array}{l}\mathrm{PK}_{3} \mathrm{AT}_{1} \\
\text { (Pupuk kandang } 7 \mathrm{~kg} \text { dan } \\
\text { ampas tahu } 7 \mathrm{~kg} \text { ) }\end{array}$ & 1,333 & 3,92 & 0,769 & 6,022 & 2,007 \\
\hline $\begin{array}{l}\mathrm{PK}_{3} \mathrm{AT}_{2} \\
\text { (Pupuk kandang } 7 \mathrm{~kg} \text { dan } \\
\text { ampas tahu } 5 \mathrm{~kg} \text { ) }\end{array}$ & 1,155 & 1,156 & 1,084 & 3,395 & 1,131 \\
\hline $\begin{array}{l}\mathrm{PK}_{3} \mathrm{AT}_{3} \\
\text { (Pupuk kandang } 7 \mathrm{~kg} \text { dan } \\
\text { ampas tahu } 3 \mathrm{~kg} \text { ) }\end{array}$ & 1,517 & 1,294 & 1,572 & 4,383 & 1,461 \\
\hline $\begin{array}{l}\text { Kontrol } \\
\text { (Tanpa Perlakuan) }\end{array}$ & 0,998 & 1,281 & 0,975 & 3,254 & 1,084 \\
\hline
\end{tabular}

Tabel 4 menunjukkan bahwa kadar klorofil a tertinggi daun pak choy (Brassica chinensis L.) yaitu pada kombinasi pupuk
$\mathrm{PK}_{3} \mathrm{AT}_{1}$ (Pupuk kandang $7 \mathrm{~kg}$ dan ampas tahu $7 \mathrm{~kg}$ ) sebesar $2,007 \mathrm{mg} / \mathrm{L}$.

Tabel 5. Hasil Perhitungan Kadar Klorofil b Daun Pak Choy (Brassica chinensis L.)

\begin{tabular}{|c|c|c|c|c|c|}
\hline \multirow{2}{*}{ Kombinasi Pupuk } & \multicolumn{3}{|c|}{ Ulangan } & \multirow{2}{*}{ Total } & \multirow{2}{*}{$\begin{array}{c}\text { Rerata Kadar } \\
\text { Klorofil b (mg/L) }\end{array}$} \\
\hline & 1 & 2 & 3 & & \\
\hline $\begin{array}{l}\mathrm{PK}_{1} \mathrm{AT}_{1} \\
\text { (Pupuk kandang } 3 \mathrm{~kg} \text { dan } \\
\text { ampas tahu } 7 \mathrm{~kg} \text { ) }\end{array}$ & 0,924 & 1,253 & 0,966 & 3,143 & 1,047 \\
\hline $\begin{array}{l}\mathrm{PK}_{1} \mathrm{AT}_{2} \\
\text { (Pupuk kandang } 3 \mathrm{~kg} \text { dan } \\
\text { ampas tahu } 5 \mathrm{~kg} \text { ) }\end{array}$ & 0,965 & 0,882 & 0,785 & 2,632 & 0,877 \\
\hline $\begin{array}{l}\mathrm{PK}_{1} \mathrm{AT}_{3} \\
\text { (Pupuk kandang } 3 \mathrm{~kg} \text { dan } \\
\text { ampas tahu } 3 \mathrm{~kg} \text { ) }\end{array}$ & 2,477 & 2,022 & 2,114 & 6,613 & 2,204 \\
\hline $\mathrm{PK}_{2} \mathrm{AT}_{1}$ & 2,301 & 2,282 & 1,898 & 6,481 & 2,160 \\
\hline
\end{tabular}




\begin{tabular}{|c|c|c|c|c|c|}
\hline $\begin{array}{l}\text { (Pupuk kandang } 5 \mathrm{~kg} \text { dan } \\
\text { ampas tahu } 7 \mathrm{~kg} \text { ) }\end{array}$ & & & & & \\
\hline $\begin{array}{l}\mathrm{PK}_{2} \mathrm{AT}_{2} \\
\text { (Pupuk kandang } 5 \mathrm{~kg} \text { dan } \\
\text { ampas tahu } 5 \mathrm{~kg} \text { ) }\end{array}$ & 1,778 & 2,266 & 2,160 & 6,204 & 2,068 \\
\hline $\begin{array}{l}\mathrm{PK}_{2} \mathrm{AT}_{3} \\
\text { (Pupuk kandang } 5 \mathrm{~kg} \text { dan } \\
\text { ampas tahu } 3 \mathrm{~kg} \text { ) }\end{array}$ & 2,161 & 2,390 & 0,899 & 5,45 & 1,816 \\
\hline $\begin{array}{l}\mathrm{PK}_{3} \mathrm{AT}_{1} \\
\text { (Pupuk kandang } 7 \mathrm{~kg} \text { dan } \\
\text { ampas tahu } 7 \mathrm{~kg} \text { ) }\end{array}$ & 2,637 & 2,367 & 2,518 & 7,522 & 2,507 \\
\hline $\begin{array}{l}\mathrm{PK}_{3} \mathrm{AT}_{2} \\
\text { (Pupuk kandang } 7 \mathrm{~kg} \text { dan } \\
\text { ampas tahu } 5 \mathrm{~kg} \text { ) }\end{array}$ & 2,605 & 2,612 & 2,642 & 7,859 & 2,619 \\
\hline $\begin{array}{l}\mathrm{PK}_{3} \mathrm{AT}_{3} \\
\text { (Pupuk kandang } 7 \mathrm{~kg} \text { dan } \\
\text { ampas tahu } 3 \mathrm{~kg} \text { ) }\end{array}$ & 2,560 & 2,723 & 2,739 & 8,022 & 2,674 \\
\hline $\begin{array}{l}\text { Kontrol } \\
\text { (Tanpa Perlakuan) }\end{array}$ & 0,505 & 0,712 & 1,44 & 2,657 & 0.885 \\
\hline
\end{tabular}

Tabel 5 menunjukkan bahwa kadar klorofil b tertinggi daun pak choy (Brassica chinensis L.) yaitu pada kombinasi pupuk
$\mathrm{PK}_{3} \mathrm{AT}_{3}$ (Pupuk kandang $7 \mathrm{~kg}$ dan ampas tahu $3 \mathrm{~kg}$ ) sebesar $2,674 \mathrm{mg} / \mathrm{L}$.

Tabel 6. Hasil Perhitungan Kadar Klorofil Total Daun Pak Choy (Brassica chinensis L.)

\begin{tabular}{|c|c|c|c|c|c|}
\hline \multirow[t]{2}{*}{ Kombinasi Pupuk } & \multicolumn{3}{|c|}{ Ulangan } & \multirow[t]{2}{*}{ Total } & \multirow{2}{*}{$\begin{array}{c}\text { Rerata Kadar Klorofi } \\
\text { Total (mg/L) }\end{array}$} \\
\hline & 1 & 2 & 3 & & \\
\hline $\begin{array}{l}\mathrm{PK}_{1} \mathrm{AT}_{1} \\
\text { (Pupuk kandang } 3 \mathrm{~kg} \text { dan } \\
\text { ampas tahu } 7 \mathrm{~kg} \text { ) }\end{array}$ & 1,046 & 1,816 & 1,504 & 4,366 & 1,455 \\
\hline $\begin{array}{l}\mathrm{PK}_{1} \mathrm{AT}_{2} \\
\text { (Pupuk kandang } 3 \mathrm{~kg} \text { dan } \\
\text { ampas tahu } 5 \mathrm{~kg} \text { ) }\end{array}$ & 1,431 & 1,786 & 1,345 & 4,562 & 1,520 \\
\hline $\begin{array}{l}\mathrm{PK}_{1} \mathrm{AT}_{3} \\
\text { (Pupuk kandang } 3 \mathrm{~kg} \text { dan } \\
\text { ampas tahu } 3 \mathrm{~kg} \text { ) }\end{array}$ & 2,399 & 1,819 & 1,703 & 5,921 & 1,973 \\
\hline $\begin{array}{l}\mathrm{PK}_{2} \mathrm{AT}_{1} \\
\text { (Pupuk kandang } 5 \mathrm{~kg} \text { dan } \\
\text { ampas tahu } 7 \mathrm{~kg} \text { ) }\end{array}$ & 2,121 & 2,089 & 1,647 & 5,857 & 1,952 \\
\hline $\begin{array}{l}\mathrm{PK}_{2} \mathrm{AT}_{2} \\
\text { (Pupuk kandang } 5 \mathrm{~kg} \text { dan } \\
\text { ampas tahu } 5 \mathrm{~kg} \text { ) }\end{array}$ & 1,713 & 1,900 & 1,907 & 5,52 & 1,84 \\
\hline $\begin{array}{l}\mathrm{PK}_{2} \mathrm{AT}_{3} \\
\text { (Pupuk kandang } 5 \mathrm{~kg} \text { dan } \\
\text { ampas tahu } 3 \mathrm{~kg} \text { ) }\end{array}$ & 1,718 & 1,976 & 1,127 & 4,821 & 1,607 \\
\hline $\begin{array}{l}\mathrm{PK}_{3} \mathrm{AT}_{1} \\
\text { (Pupuk kandang } 7 \mathrm{~kg} \text { dan } \\
\text { ampas tahu } 7 \mathrm{~kg} \text { ) }\end{array}$ & 2,943 & 8,38 & 2,351 & 13,674 & 4,558 \\
\hline $\begin{array}{l}\mathrm{PK}_{3} \mathrm{AT}_{2} \\
\text { (Pupuk kandang } 7 \mathrm{~kg} \text { dan } \\
\text { ampas tahu } 5 \mathrm{~kg} \text { ) }\end{array}$ & 2,759 & 2,765 & 2,719 & 8,243 & 2,747 \\
\hline $\mathrm{PK}_{3} \mathrm{AT}_{3}$ & 3,06 & 2,964 & 3,226 & 9,25 & 3,083 \\
\hline
\end{tabular}




\begin{tabular}{llllll}
\hline $\begin{array}{l}\text { (Pupuk kandang 7 kg dan } \\
\text { ampas tahu 3 kg) }\end{array}$ & & & & & \\
\hline $\begin{array}{l}\text { Kontrol } \\
\text { (Tanpa Perlakuan) }\end{array}$ & 1,239 & 1,621 & 1,199 & 4,059 & 1,353 \\
\hline
\end{tabular}

Tabel 6 menunjukkan bahwa kadar klorofil total tertinggi daun pak choy (Brassica chinensis L.) yaitu pada kombinasi pupuk $\mathrm{PK}_{3} \mathrm{AT}_{1}$ (Pupuk kandang 7 $\mathrm{kg}$ dan ampas tahu $7 \mathrm{~kg}$ ) sebesar 4,558 $\mathrm{mg} / \mathrm{L}$.

\section{Pembahasan}

Berdasarkan data hasil kadar klorofil daun pakcoy (Brassica chinensis L.) setelah pemberian pupuk kandang dan ampas tahu sebagaimana pada Tabel 4.1-4.3 maka dapat dilihat bahwa kadar klorofil daun pak choy (Brassica chinensis L.) untuk setiap kombinasi pupuk kandang dan ampas tahu yang berbeda mengalami peningkatan. Kadar klorofil a tertinggi terdapat pada kombinasi pupuk kandang $7 \mathrm{~kg}$ dan ampas tahu $7 \mathrm{~kg}\left(\mathrm{PK}_{3} \mathrm{AT}_{1}\right)$ dengan kadar klorofilnya 2,007 $\mathrm{mg} / \mathrm{L}$, kadar klorofil $\mathrm{b}$ tertinggi terdapat pada kombinasi pupuk kandang 7 $\mathrm{kg}$ dan ampas tahu $3 \mathrm{~kg}\left(\mathrm{PK}_{3} \mathrm{AT}_{3}\right)$ dengan kadar klorofilnya 2,674 mg/L, dan kadar klorofil total tertinggi terdapat pada kombinasi pupuk kandang $7 \mathrm{~kg}$ dan ampas tahu $7 \mathrm{~kg}\left(\mathrm{PK}_{3} \mathrm{AT}_{1}\right)$ dengan kadar klorofilnya $4,558 \mathrm{mg} / \mathrm{L}$.

Jika dilihat pada klorofil a, b maupun klorofil total, tertinggi pada kombinasi $\mathrm{PK}_{3} \mathrm{AT}_{1}$ dan $\mathrm{PK}_{3} \mathrm{AT}_{3}$. kombinasi $\mathrm{PK}_{3} \mathrm{AT}_{1}$ merupakan kombinasi antara pupuk kandang sebanyak $7 \mathrm{~kg}$ dan ampas tahu sebanyak $7 \mathrm{~kg}$ dan perlakuan $\mathrm{PK}_{3} \mathrm{AT}_{3}$ merupakan kombinasi antara pupuk kandang sebanyak $7 \mathrm{~kg}$ dan ampas tahu 3 $\mathrm{kg}$, dapat dilihat bahwa pada klorofil a, b dan klorofil total peningkatan pupuk yang terjadi adalah pada pupuk kandang $7 \mathrm{~kg}$, artinya pupuk yang sangat berpengaruh pada peningkatan klorofil adalah pada pupuk kandang. Pupuk kandang memiliki unsur nitrogen yang lebih dominan dibandingkan dengan ampas tahu yang memiliki unsur nitrogen yang rendah (Rahmina, dkk. 2017).

Dari penelitian Wijaya, (2000) yang menyatakan penambahan nitrogen pupuk kandang pada tanaman dapat meningkatkan, dan mendorong pertumbuhan organ-organ yang berkaitan dengan fotosintesis. Daun yang mendapat suplanitrogen akan membentuk daun yang memiliki helaian daun yang lebih luas dengan kandungan-kandungan klorofil yang lebih tinggi, sehingga tanaman mampu menghasilkan karbohidrat dalam jumlah yang tinggi untuk mendukung pertumbuhan vegetatif. Hasil penelitian yang sama juga dinyatakan oleh, Djumali dan Nurnasari (2012) yang menunjukkan bahwa dosis pupuk nitrogen yang digunakan dapat mempengaruhi perubahan fisiologi tanaman yang meliputi kandungan klorofil daun, bobot spesifik daun, laju fotosintesis, efisiensi cahaya mereduksi $\mathrm{CO}_{2}$, dan koefisien respirasi pemeliharaan daun. Dengan demikian pupuk kandang dan ampas tahu dengan jumlah yang cukup bahkan lebih dapat meningkatkan kadar klorofil pada daun pak coy (Brassica chinensis L.).

Pada pupuk kandang mengandung nitrogen yang lebih banyak dibandingkan dengan ampas tahu. Namun jika ampas tahu ditambahkan dengan komposisi yang lebih banyak maka dapat meningkatkan nitrogen dalam tanah sehingga dapat mempengaruhi pertambahan jumlah daun pada tanaman (Rahmina, dkk. 2017). Menurut Harahap, dkk. (2015) unsur nitrogen meningkatkan fotosintesis dan hasilnya dapat diakumulasikan pada seluruh bagian tanaman untuk pertumbuhan, termasuk untuk pembentukan daun. Selain itu, semakin banyak unsur nitrogen yang terkandung dalam media tanam maka semakin banyak pula klorofil yang dibentuk untuk proses fotosintesis sehingga menyebabkan semakin banyak nutrisi yang tersedia bagi pertumbuhan tanaman.

Berdasarkan hasil penelitian kadar klorofil daun pak coy (Brassica chinensis L.) setelah pemberian pupuk kandang dan ampas tahu, kadar klorofil a terendah daun Pak Choy (Brassica chinensis L.) yaitu pada kombinasi $\mathrm{PK}_{2} \mathrm{AT}_{3}$ (Pupuk kandang $5 \mathrm{~kg}$ dan ampas tahu $3 \mathrm{~kg}$ ) sebesar 0,482 $\mathrm{mg} / \mathrm{L}$. Kadar klorofil b terendah daun Pak Choy (Brassica chinensis L.) yaitu pada 
kombinasi $\mathrm{PK}_{1} \mathrm{AT}_{2}$ (Pupuk kandang $3 \mathrm{~kg}$ dan ampas tahu $5 \mathrm{~kg}$ ) sebesar 0,877 $\mathrm{mg} / \mathrm{L}$. Kadar klorofil total terendah daun Pak Choy (Brassica chinensis L.) yaitu pada kombinasi $\mathrm{PK}_{2} \mathrm{AT}_{2}$ (Pupuk kandang $5 \mathrm{~kg}$ dan ampas tahu $5 \mathrm{~kg}$ ) sebesar $1,84 \mathrm{mg} / \mathrm{L}$.

Pada klorofil a, b maupun klorofil total, terendah pada kombinasi $\mathrm{PK}_{2} \mathrm{AT}_{3}, \mathrm{PK}_{1} \mathrm{AT}_{2}$ dan $\mathrm{PK}_{2} \mathrm{AT}_{2}$. Perlakuan $\mathrm{PK}_{2} \mathrm{AT}_{3}$ merupakan kombinasi antara pupuk kandang sebanyak $5 \mathrm{~kg}$ dan ampas tahu sebanyak $3 \mathrm{~kg}$ dan kombinasi $\mathrm{PK}_{1} \mathrm{AT}_{2}$ merupakan kombinasi antara pupuk kandang sebanyak $3 \mathrm{~kg}$ dan ampas tahu $5 \mathrm{~kg}$, serta kombinasi $\mathrm{PK}_{2} \mathrm{AT}_{2}$ merupakan kombinasi antara pupuk kandang sebanyak $5 \mathrm{~kg}$ dan ampas tahu 5 $\mathrm{kg}$, dapat dilihat bahwa pada klorofil a, b dan klorofil total mengalami penurunan komposisi pupuk yang terjadi adalah pada pupuk kandang $5 \mathrm{~kg}$, artinya pupuk yang sangat berpengaruh pada peningkatan klorofil adalah pada pupuk kandang.

Komposisi pupuk kandang yang menurun dapat mempengaruhi kandungan unsur hara pada media tanam pak coy. Menurut Rahmina, dkk. (2017) kecukupan unsur hara bagi pertumbuhan tanaman sangat berpengaruh. Unsur hara yang cukup bagi pertumbuhan tanaman dapat membuat tanaman tumbuh dengan optimal. Sedangkan tanaman yang kekurangan unsur hara akan menyebabkan tanaman tersebut tidak dapat tumbuh secara optimal. Unsur hara yang dapat mendukung pertumbuhan tanaman pak coy untuk tumbuh dengan baik salah satunya yaitu unsur hara makro yakni nitrogen, fosfor dan kalium (NPK) dimana unsur ini dibutuhkan dalam jumlah yang banyak. Unsur makro (NPK) ini terdapat dalam pupuk kandang dan ampas tahu.

Menurut Sutedjo (2010), unsur N berfungsi meningkatkan pertumbuhan tanaman, menyehatkan klorofil, meningkatkan kadar protein dalam tanaman, meningkatkan kualitas tanaman yang menghasilkan daun. Ketersediaan nitrogen yang cukup dan dalam keadaan seimbang dengan unsur lain dapat meningkatkan pertumbuhan vegetatif tanaman. Kandungan unsur $P$ yang terdapat dalam ampas tahu memiliki kriteria sangat tinggi. Unsur P merupakan bahan pembentuk inti sel, berperan penting dalam pembelahan sel serta perkembangan jaringan meristematik sehingga berpengaruh untuk pembentukan bakal daun dan memperluas ukuran daun. Kandungan unsur $\mathrm{K}$ yang terdapat dalam ampas tahu juga memiliki kriteria yang sangat tinggi. Unsur $\mathrm{K}$ merupakan pengaktif dari sejumlah besar enzim yang penting untuk fotosintesis dan respirasi pada tanaman.

\section{Implikasi Penelitian Dalam Pembelajaran Biologi}

Implikasi hasil penelitian ini pada mata kuliah fisiologi tumbuhan dalam bentuk bahan ajar untuk mahasiswa. Pada mata kuliah fisiologi tumbuhan tidak terlepas dari materi pembelajaran tentang fotosintesis dalam hal ini klorofil, sehingga sangat penting untuk menyediakan suatu pedoman belajar untuk memfasilitasi mahasiswa dalam melakukan proses pembelajaran berupa bahan ajar.

Klorofil adalah pigmen berwarna hijau yang terdapat dalam kloroplas. Pada tumbuhaan tingkat tinggi, kloroplas terutama terdapat pada jaringan parenkim palisade dan parenkim spons daun. Dalam kloroplas, pigmen utama klorofil serta karotenoid dan xantofil terdapat pada membran tilakoid (Sumenda., dkk 2011). Klorofil berasal dari proplastida yaitu plastida yang belum dewasa, kecil dan hampir tidak berwarna dan sedikit atau tanpa membran dalam. Proplastida membelah saat embrio berkembang, dan menjadi kloroplas ketika daun dan batang terbentuk pada organ yang terkena cahaya matahari, kloroplas mudah akan aktif membelah (Sumenda., dkk 2011).

Bahan ajar ini dibuat dengan tujuan untuk menambah pengetahuan mahasiswa sebagai bahan referensi atau pembelajaran khususnya bagi mahasiswa Program Studi Pendidikan Biologi atau Jurusan Biologi dalam mata kuliah Fisiologi Tumbuhan. Bahan ajar ini diharapkan dapat bermanfaat bagi mahasiswa secara khusus dan masyarakat, serta pelayanan pertanian, yaitu untuk menambah atau memberikan informasi dan pengetahuan tentang kadar klorofil daun pakcoy setelah pemberian pupuk kandang dan ampas tahu. 


\section{KESIMPULAN}

Kesimpulan yang dapat diambil dalam penelitian "Kadar Klorofil Pada Daun PakChoy Setelah Pemberian Pupuk Kandang dan Ampas Tahu dan Pemanfaatanya Sebagai Penunjang Bahan Ajar Mata Kuliah Fisiologi Tumbuhan" adalah:

1. Kadar klorofil $\mathrm{a}, \mathrm{b}$ dan total pada daun pakchoy (Brassica chinensis L.) setelah kombinasi pupuk kandang dan ampas tahu sebagaimana Tabel 4.1 menunjukkan bahwa kadar klorofil a tertinggi daun pak choy (Brassica chinensis L.) yaitu pada kombinasi $\mathrm{PK}_{3} \mathrm{AT}_{1}$ (Pupuk kandang $7 \mathrm{~kg}$ dan ampas tahu $7 \mathrm{~kg}$ ) sebesar $2,007 \mathrm{mg} / \mathrm{L}$. Hasil perhitungan kadar klorofil b pada Tabel 4.2 menunjukkan bahwa kadar klorofil b tertinggi daun pak choy (Brassica chinensis L.) yaitu pada kombinasi $\mathrm{PK}_{3} \mathrm{AT}_{3}$ (Pupuk kandang $7 \mathrm{~kg}$ dan ampas tahu $3 \mathrm{~kg}$ ) sebesar 2,674 $\mathrm{mg} / \mathrm{L}$. Dan pada tabel 4.3 menunjukan bahwa kadar klorofil total tertinggi daun pak choy (Brassica chinensis L.) yaitu pada kombinasi $\mathrm{PK}_{3} \mathrm{AT}_{1}$ (Pupuk kandang $7 \mathrm{~kg}$ dan ampas tahu $7 \mathrm{~kg}$ ) sebesar $4,558 \mathrm{mg} / \mathrm{L}$.

2. Implikasi dari penelitian ini berupa bahan ajar bagi mahasiswa pada mata kuliah fisiologi tumbuhan.

\section{DAFTAR PUSTAKA}

Danial, M., Taufiq, N.A.S., dan Sanusi, W. 2009. Pemanfaatan Zeolit dan Bokashi Ampas Tahu untuk Menekan Konsentrasi Nikel dan Meningkatkan Pertumbuhan Tanaman Jagung (Penelitian Lapang II).http://digilib.unm.ac.id/dowload.php?i $\mathrm{d}=56$. Diakses pada tanggal 5 Maret 2012.

Djumali, Nurnasari. E. 2012. Keragaman Pertumbuhan dan Hasil Populasi Tanaman Jarak Pagar IP-3A. Bul. Tembakau Serat Minyak Industri 4:1523

Harahap, A, D. Nurhidayah, T., \& Saputra, S. I, 2015. Pengaruh Pemberian Ampas Tahu Terhadap Pertumbuhan Bibit Kopi Robusta (Coffea Canphora Pierre) Dibawah Naungan Kelapa Sawit. JOM Fapertafol. 2 No.1,
Hidayat, A. A. A \& Musrifatul Uliyah. 2014. Pengantar kebutuhan dasar manusia. Edisi 2. Jakarta: Salemba Medika.

Mayadewi, N. N. A. 2007. Pengaruh Jenis Pupuk Kandang dan Jarak Tanam Terhadap Pertumbuhan Gulma dan Hasil Jagung Manis. Agritrop 26 (4): 153-159.

Mulyasa, E. 2006. Kurikulum yang di sempurnakan. Bandung: PT Remaja Rosdakarya.

Murti, B. W., Baskara, M dan Santosa, M. 2016. Pengaruh Biourine Dan Jenis Pupuk Terhadap Pertumbuhan Dan Hasil Tanaman Pak Choy (Brassica Chinensis L.)

Napitupulu, D., dan Winarto, L. 2010. Pengaruh Pemberian Pupuk $\mathrm{N}$ dan $\mathrm{K}$ Terhadap Pertumbuhan dan Produksi Bawang Merah. J. Hort. 20(1) : 27-35.

Ningsih, Ratna. (2011). Efektivitas Paket Perada terhadap Intesitas Nyeri pada Remaja dengan Dismenore di SMAN Kecamatan Curup. Tesis Universitas Inndonesia

Nurdin, Kushart, C. M., Tanziha, I., Januwati, M. 2009. Kandungan Klorofil Berbagai Jenis Daun Tanaman dan CuTurunan Klorofil serta Karakteristik Fisiko-Kimianya. Jurnal Gizi dan Pangan, Maret 2009 4(1): 13 - 19.

Parman, S. 2007. Pengaruh Pertumbuhan Pupuk Organik Cair Terhadap Pertumbuhan Tanaman Kentang (Solanum tuberosum L.). Semarang: Laboratorium Biologi Struktur dan Fungsi Tumbuhan Jurusan Biologi Fakultas FMIPA UNDIP.

Rahmina, W., Nurlaelah., Handayani. 2017. Pengaruh Perbedaan Komposisi Limbah Ampas Tahu Terhadap Pertumbuhan Tanaman Pak Choy (Brassica Rapa L. Ssp. Chinensis) Quaagga, Volume 9 No. 2, 38-46.

Sadewa, D. P. P. 2016. Pemanfaatan Padatan Digestat Sebagai Campuran Media Tanam Pak Choy (Brassica Rapa L.) Dengan Sistem Irigasi Bawah Permukaan. Skripsi. Fakultas Pertanian. Universitas Lampung. Bandar Lampung.

Setiari, N., dan Nurchayati, Y. 2009. Eksplorasi Kandungan Klorofil pada beberapa Sayuran Hijau sebagai Alternatif Bahan Dasar Food 
Supplement. BIOMA, Vol 11, No. 1, Hal. 6-10 Juni 2009. ISSN: 1410-8801.

Song-Ai, N., dan Banyo, Y. 2011. Konsentrasi Klorofil Daun Sebagai Indikator Kekurangan Air Pada Tanaman. Jurnal IImiah Sains Vol. 11 No. 2, Oktober 2011. Hal: 166-173.

Sumenda, 2011. Analisis Kandungan Klorofil Daun Mangga (Mangifera indica L.) Pada Tingkat Perkembangan Daun Yang Berbeda. Bioslogos, 1, (1).

Suntoro. 2002. Pengaruh Penambahan Bahan Organik, Dolomit dan $\mathrm{KCl}$
Terhadap Kadar Klorofil dan Dampaknya Pada Hasil Kacang Tanah (Arachis hypogea L.). BioSMART. Vol. 4 No. 2:36-46. (Terakreditasi Nasional No. 02/DIKTI/Kep/2002).

Sutedjo, M. 2010. Pupuk dan Cara Pemupukan. Jakarta : Rineka Cipta

Wijaya, K.2000. Pengaruh konsentrasi dan frekuensi pembberian pupuk organik cair hasil perombakan anaerob limbah makanan terhadap pertumbuhan tanaman sawi (Brasicca juncea L.) Skripsi. Universitas Sebelas Maret. 